\title{
Influence of nitrogen fertilization and green manure on the economic feasibility of no-tilled wheat in the Cerrado ${ }^{1}$
}

\author{
Douglas de Castilho Gitti ${ }^{2 *}$, Orivaldo Arf ${ }^{3}$, Mariana Melero ${ }^{4}$, Ricardo Antonio Ferreira Rodrigues ${ }^{3}$, \\ Maria Aparecida Anselmo Tarsitano ${ }^{3}$
}

\begin{abstract}
The search for higher profitability in wheat crop with cost reduction technologies that may promote sustainability is an important matter in Brazilian agriculture. This study evaluated the profitability of no-tilled wheat, reducing nitrogen topdressing doses with the cultivation of green manure before the wheat crop. The experiment was carried out in Selvíria (MS), Brazil, in 2009/10. The experiment was arranged in a randomized block design with 36 treatments in splitplots and four replicates. The plots were formed by six types of green manure: Cajanus cajan L. BRS Mandarin, Crotalaria juncea L., Pennisetum americanum L. BRS 1501, fallow area and mixed cropping of Pennisetum americanum L. + Cajanus cajan L. and Pennisetum americanum L. + crotalaria which provided straw for no-tilled wheat in the winter, following the rice crop in the summer. The subplots were formed by six levels of topdressing nitrogen $(0,25,50$, 75,100 and $125 \mathrm{~kg} \mathrm{~N} \mathrm{ha}^{-1}$ ) using urea as a nitrogen source. The wheat grown after green manure in the previous winter crop, with no nitrogen topdressing and a rate of $25 \mathrm{~kg} \mathrm{ha}^{-1} \mathrm{~N}$, had more frequently production costs above the gross income. Wheat production cost after the mixed cropping Pennisetum americanum L. + Cajanus cajan L. and Pennisetum americanum L. + Crotalaria juncea L. from the previous winter crop, combined with nitrogen rates of 50 and $75 \mathrm{~kg} \mathrm{~N}$ $\mathrm{ha}^{-1}$, provided better profitability compared with the other green manures evaluated.
\end{abstract}

Key words: Triticum aestivum L., production cost, Crotalaria juncea L., pigeonpea, millet, residual effect.

\section{RESUMO}

\section{Influência da adubação nitrogenada e do cultivo de adubos verdes na viabilidade econômica do trigo em plantio direto no cerrado}

É importante a busca por melhores rentabilidades para a cultura do trigo por meio de tecnologias que reduzam custos de produção e proporcionem sustentabilidade à agricultura brasileira. Assim, o objetivo deste trabalho foi avaliar a rentabilidade da cultura do trigo em sistema plantio direto, visando reduzir doses de nitrogênio em cobertura, pelo cultivo de adubos verdes anterior ao do trigo. O experimento foi realizado em Selvíria (MS), Brasil, no ano 2009/10. O delineamento utilizado foi o de blocos casualizados com 36 tratamentos, em parcelas subdividas, com quatro repetições. As parcelas foram formadas por seis tipos de adubos verdes (guandu BRS Mandarim, Crotalaria juncea, milheto BRS 1501, pousio e os consórcios milheto + guandu e milheto + crotalária), que forneceram palha para o plantio direto do trigo no inverno, após a cultura de arroz na safra de verão. As subparcelas foram formadas por seis doses de nitrogênio $\left(0,25,50,75,100\right.$ e $125 \mathrm{~kg} \mathrm{ha}^{-1}$ de $\left.\mathrm{N}\right)$ em uma aplicação em cobertura, ten-do como fonte a ureia. $\mathrm{O}$ trigo

\footnotetext{
Recebido para publicação em 25/03/2011 e aprovado em 16/12/2011

${ }^{1}$ Research financed by FAPESP and CNPq.

${ }^{2}$ Agronomist Engineer, Master Science. Universidade Estadual Paulista Júlio de Mesquita Filho, Faculdade de Engenharia de Ilha Solteira, Departamento de Fitotecnia, Tecnologia de Alimentos e Sócio Economia, Av. Brasil, Centro, 56, Caixa Postal 31, 15385-000 Ilha Solteira, São Paulo, Brazil. dcgitti @aluno.feis.unesp.br *Corresponding author.

${ }^{3}$ Agronomist Engineer, Doctor Science. Universidade Estadual Paulista Júlio de Mesquita Filho, Faculdade de Engenharia de Ilha Solteira, Departamento de Fitotecnia, Tecnologia de Alimentos e Sócio Economia, Av. Brasil, Centro, 56, Caixa Postal 31, 15385-000 Ilha Solteira, São Paulo, Brazil. arf@agr.feis.unesp.br, maat@agr.feis.unesp.br, ricardo@agr.feis.unesp.br
} 
cultivado, após a semeadura dos adubos verdes na safra de inverno anterior, sem a aplicação de nitrogênio em cobertura e na dose $25 \mathrm{~kg} \mathrm{ha}^{-1}$ de N, apresentou com maior frequência custos de produção superior à receita bruta. $\mathrm{O}$ custo de produção de trigo cultivado após os consórcios de milheto + guandu e milheto + crotalária na safra de inverno anterior, associado a doses de nitrogênio de 50 e $75 \mathrm{~kg} \mathrm{ha}^{-1} \mathrm{de} \mathrm{N}$, proporcionou maior lucratividade em relação aos demais adubos verdes avaliados.

Palavras-chave: Triticum aestivum L., custo de produção, Crotalaria juncea L., guandu, milheto, efeito residual.

\section{INTRODUCTION}

World production of wheat in 2009/10 was of 680.3 million tons. A reduction of $5.5 \%$ is expected for the current crop with a total production of 643.0 million tons. The global consumption in 2010 was of 661.2 million tons, showing an increase of $7 \%$ compared to the $2006 / 07$ crop, which was of 615.6 million tons (Agrianual, 2011). The Brazilian wheat production for the $2010 / 11$ harvest had a $14.6 \%$ increase equivalent to 5.9 million tons in relation to the production of the previous year. The favorable climate, unlike the previous harvest, resulted in a $24.3 \%$ productivity gain (National Supply Company - CONAB, 2011).

The increased production and productivity promoted by favorable climatic factors and the use of viable technologies is still not enough to the meet the domestic consumption, which reached approximately 10 million tons in the last 10 years. Data from the CONAB (2011) point out that by July 2010, wheat grain importation accounted for just over 3.9 million tons, or $38.2 \%$ of domestic consumption, with 2.6 million tons originated from Argentina. It is a fact that wheat production in Brazil is strategical for food security, soil conservation and crop rotation, but, profitability is the factor that makes amateurs into professional farmers.

In the 2010/11 harvest, the state of Parana produced $52.4 \%$ of the national wheat production with an operating cost of USD 34.86/bushel in the region of Cascavel (PR), while the average for the past 10 years in the same region corresponded to BRL $24.56 / 60 \mathrm{~kg}$ bushel with prices well below the costs. The search for alternatives to benefit the producer with cost-optimizing technologies such as new cultivars with high productivity and superior industrial quality; nutrient management, especially nitrogen and the expansion of this crop to other regions of Brazil, could meet the Brazilian consumption deficit. At the same time, this could also result in exportable surpluses, since the prices in the international market, between June and August 2010 increased in 43\% against 10\% in Paraná, the largest wheat producing state in Brazil, (Agrianual, 2011).

The estimated operating expenses of wheat in Paraná in minimum tillage for the period of November 2010 was of BRL1,328.00 ha-1. The fertilizers, which are the highest operating costs, corresponded to $18.5 \%$ of the costs, while mechanized operations and seed acquisition corresponded to 18.2 and $15.7 \%$ of the operating costs, respectively (SEAB / Deral, 2011).

The Midwest and Southeast regions account for only $6 \%$ of the national wheat production, with 356,1 tons. In Minas Gerais, the costs of the wheat production system in the conventional tillage under center pivot irrigation were of BRL 2,316.00 $\mathrm{ha}^{-1}$ for the 2010/11 harvest, with a negative sale margin of $1 \%$ (loss of BRL $\$ 21.00 \mathrm{ha}^{-1}$ ). In the 2010/11 harvest in Mato Grosso do Sul, no-tillage wheat in a rainfed area, showed production cost of BRL $\$ 1,258.00 \mathrm{ha}^{-1}$ and a negative margin of $11 \%$ (loss of BRL $\$ 124.00 \mathrm{ha}^{-1}$ ) over the production cost (Agrianual, 2011).

Cánovas et al. (2004) evaluated the profitability of irrigated no-tilled wheat in the State of Goiás and obtained yields above $5000 \mathrm{~kg} \mathrm{ha}^{-1}$ with production cost of BRL\$ $1,281.00 \mathrm{ha}^{-1}$ in the 2001 harvest. The authors argue that the wheat crop in the state of Goias and in the Midwest appears as a new alternative for the grain production in crop rotation and no-tillage systems. Nevertheless, the technical recommendations based on research should be considered, mainly the altitude of the location, sowing date, irrigation management and the use quality seeds.

Mineral nutrition has an effect on yield, and nitrogen is the nutrient quantitatively most important and with greater impact (Lamothe, 1998; Sylvester-Bradley et al., 2001). Trindade et al. (2006) evaluated an irrigated wheat crop in succession to soybean in the State of Goiás, in the 2003 harvest and found that the nitrogen rate of $73 \mathrm{~kg}$ ha${ }^{1}$ was economically viable. The correct management of irrigation and nitrogen rates is important to update technical recommendations and provide technologies for economically satisfactory productions (Caviglia \& Sadras, 2001; Zagonel et al., 2002, Li \& Rao, 2003).

Seventy-five percent of the cultivar characteristics of industrial quality and yield are determined by inherent genetic factors. Climatic conditions and crop management determined the 25\% remaining (Yearbook, 2001). In Selvíria (MS), Teixeira Filho et al. (2010), in an irrigated wheat crop, obtained the highest gain margins using topdressed ammonium sulfate with application of $50 \mathrm{~kg} \mathrm{ha}^{-1} \mathrm{~N}$,

Rev. Ceres, Viçosa, v. 59, n.2, p. 246-253, mar/abr, 2012 
providing gross gain margins of BRL\$ 541.8 and BRL\$ 926.69 $\mathrm{ha}^{-1}$ for cultivar E 21 and BRL \$ 585.89 and BRL\$ $998.62 \mathrm{ha}^{-1}$ for cultivar IAC 370 , considering the atypical prices of 2007 and 2008 .

Given the difficulties found by farmers with the low wheat prices, the crop response to nitrogen and the possibility of nitrogen supply through biological fixation by legume species, this work assessed the profitability of no-tillage wheat crop in relation to nitrogen rates in succession to green manures in the Cerrado.

\section{MATERIALS AND METHODS}

The experiment was carried out in the agricultural year 2009/10 in the experimental area of the Faculty of Engineering - UNESP - Ilha Solteira campus, $51^{\circ} 22^{\prime}$ longitude West and $20^{\circ} 22^{\prime}$ latitude South, $335 \mathrm{~m}$ altitude. The soil is a typical epi-eutrophic alic Red Latosol, clayey texture. The region has average annual rainfall of 1370 $\mathrm{mm}$, average annual temperature of $23.5^{\circ} \mathrm{C}$, and relative humidity between 70 and $80 \%$ (annual average).

The experiment was arranged in a randomized block design with 36 treatments in splitplots ( $6 \times 6$ factorial) and four replicates. The plots were formed by six types of green manure: pigeon pea BRS Mandarin, Crotalaria juncea, millet BRS 1501, fallow area and millet + pigeon pea intercropping and millet + crotalaria intercropping, which provided the straw for no-tilling wheat. The subplots were treated with different nitrogen levels $(0,25,50,75$, 100 and $125 \mathrm{~kg} \mathrm{~N} \mathrm{ha}^{-1}$ ) in a single nitrogen topdressing application using urea as source.

The hard grain wheat cultivar IAC 370 (bread type), of medium cycle, was used in the experiment. This cultivar is well adapted to the regions of São Paulo and showed mean yield of $4296 \mathrm{~kg} \mathrm{ha}^{-1}$ under sprinkler irrigation in six locations of the state (Melo et al., 1999).

Green manure was sown in a no-tilling system on the 17th of August 2009. The area was marked with a mechanical planter, in $0.45 \mathrm{~m}$ row spacing. Pigeonpea, crotalaria and millet were manually sown using hand jab planters, in the following quantities: 12,15 and $15 \mathrm{~kg} / \mathrm{ha}^{-1}$, respectively. For the mixed cropping millet + pigeon pea and millet + crotalaria, the row spacing and seed density were similar to single crops and the green manures were alternated between the lines, representing half of the expenses with millet seeds used in the single crops, i.e., $7.5 \mathrm{~kg} \mathrm{ha}^{-1}$, whereas pigeon pea and crotalaria used 6 and $7.5 \mathrm{~kg} \mathrm{ha}^{-1}$ of seeds, respectively.

The fallow area was covered predominantly by Brachiaria decumbens Stapf and in smaller quantities Commelina benghabensis L. (dayflower), Euphorbia heterophylla L. (mexican fire plant) and Bidens pilosa $\mathrm{L}$. (black jack). Seventy-two days after sowing, the green manures were treated with desiccant herbicide. Green residue was managed using a Triton shredder and facilitate the next crop sowing. The area was then cultivated with rice in the summer crop, sown on November 16th, 2009, and harvested on February 25th, 2010. After harvesting, the area remained fallow until the wheat sowing.

The experimental area has been used in a no-tillage system since the agricultural year of 1998/99. Before installation, soil samples were collected and chemically analyzed with the following results: $\mathrm{pH}\left(\mathrm{CaCl}_{2}\right)=4.8 ; \mathrm{OM}=$ $17.0 \mathrm{~g} \mathrm{dm}^{-3}, \mathrm{P}($ resin $)=13 \mathrm{mg} \mathrm{dm}^{-3}, \mathrm{~K}=2.9 \mathrm{mmol}_{\mathrm{c}} \mathrm{dm}^{-3}, \mathrm{Ca}=$ $24.0 \mathrm{mmol}_{\mathrm{c}} \mathrm{dm}^{-3}, \mathrm{Mg}=13.0 \mathrm{mmol}_{\mathrm{c}} \mathrm{dm}^{-3}, \mathrm{Al}^{+3}=1 \mathrm{mmol}_{\mathrm{c}} \mathrm{dm}^{-3}$, $\mathrm{H}+\mathrm{Al}=46.0 \mathrm{mmol}_{\mathrm{c}} \mathrm{dm}-3$, and BS (base saturation) $=46 \%$.

Wheat seeds were treated with the insecticide thiodicarb ( $0.15 \mathrm{~g}$ i.a. $\left.100 \mathrm{~kg}^{-1} / \mathrm{seed}\right)$ for soil pest control. Mechanical sowing was carried out 5 days after management of the area with desiccants on May $11^{\text {th }} 2010$. Basic fertilization consisted of $250 \mathrm{~kg} \mathrm{ha}^{-1}$ of the formula 04-30-10 and topdressing in single application on June $25^{\text {th }}, 2010,38$ days after seedling emergence.

The plots consisted of 13 rows spaced $0.17 \mathrm{~m}$ apart and $6 \mathrm{~m}$ long. The usable area consisted of 11 central rows of each plot, discarding $0,5 \mathrm{~m}$ at the end of each row.

The effective operating costs (EOC) of wheat production for each treatment were estimated by the sum of manual and mechanical operations and inputs values, extrapolated to 1 hectare. Only the direct input costs were considered. No other expenses were considered and depreciation and interest costs were as proposed by Matsunaga et al., 1976. The prices for the agricultural inputs were surveyed from retailers in the northwestern region of São Paulo. The prices of services in February 2011 were considered for mechanized and manual operational costs paid by regional producers for outsourcing operations. The yield obtained in the treatments evaluated helped to calculate the income and the price of grain wheat using the average values from the last five years (2007-2011) published by the Institute of Agricultural Economics - IEA (2011). Profitability in each treatment was evaluated using the benefit/ EOC ratio, and the gross revenue from wheat commercialization was divided by the total input and operations costs (EOC). The interactions between green manures and nitrogen levels with benefit/ EOC > 1.0 were considered economically viable.

The analysis of variance and the Tukey test $(5 \%$ probability) were used to assess yield data. Regression analysis of the effects of Nitrogen rates on each green manure performance was carried out.

\section{RESULTS AND DISCUSSION}

The costs with mechanized and manual operations and inputs used in green manures and wheat cultivation in 
the no-tillage system are shown in Table 1 . The values correspond to those practiced in the northwest region of São Paulo, and refer to the survey carried out with regional sellers to approach the producer's reality.

The operating costs related to nitrogen and the use of green manures in wheat cultivation are shown in Table 2. The wheat production cost in the fallowing area was of BRL $\$ 1,129.85 \mathrm{ha}^{-1}$, and the remaining production costs referred to green manure sowing operation (USD\$ 96.00 $\mathrm{ha}^{-1}$ ), straw managing with a Triton (BRL\$ $52.25 \mathrm{ha}^{-1}$ ) and seed acquisition expenses: pigeon pea seeds BRS Mandarin (BRL\$ $\left.45.60 \mathrm{ha}^{-1}\right)$, millet BRS $1501\left(\$ 22.50 \mathrm{ha}^{-1}\right)$, Crotalaria juncea $\left(\mathrm{R} \$ 97.50 \mathrm{ha}^{-1}\right)$ and the mixed cropping millet + pigeonpea (USD\$ $\left.11.25 \mathrm{ha}^{-1}+\mathrm{BRL} \$ 22.80 \mathrm{ha}^{-1}\right)$ and millet + crotalaria (USD\$11.25 ha- + BRL\$ $4875 \mathrm{~h}^{-1}$ ). Regarding the nitrogen rates, the costs referred to mechanized topdressing application (BRL\$33.00 ha-1) and the costs with the urea rates $25,50,75,100$ and $125 \mathrm{~kg}$ ha ${ }^{1}$ of $\mathrm{N}$, with costs per hectare equivalent to BRL\$ 67.71, 135.42, 203.13, 270.84, and 338.55, respectively.

The highest production costs were obtained in the treatments that used crotalaria as green manure in all rates evaluated and in the following sequence: the mixed cropping millet + crotalaria, single crop of pigeon pea, mixed cropping millet + pigeon pea and, lastly, fallow, which had the lowest production cost (BRL\$ 1,129.85 ha-1). The benefits from the use of crotalaria as green manure in sugarcane reform areas (an important crop in the region), increases the demand for crotalaria seeds, increasing the costs of the production systems in which it is used.

The mixed cropping systems had lower costs than crotalaria and pigeon pea in single crops, being considered as viable alternatives for the use of quality legume seeds at a lower cost, demanding a less amount of seeds than single crops. Mixed cropping of green manures is more effective for the production of dry matter and accumulation and release of macronutrients (Teixeira et al., 2009). Therefore, the mixed cropping of grasses and legumes is benefitted from the characteristics of the legumes, such as nitrogen fixation (100 to $300 \mathrm{~kg} \mathrm{ha}^{-1}$ per year), rapid development, straw production for ground cover, nematode control (Embrapa, 2011); and from the grasses, reducing productions costs of green manure by lowering the seed cost, as with millet.

Table 1. Costs of the mechanized and manual operations, and inputs obtained from the wheat crop, in relation to nitrogen rates and green manures in Selvíria (MS), 2010/11 harvest

\begin{tabular}{|c|c|c|c|c|c|}
\hline \multicolumn{2}{|c|}{ Description } & Specif. & Quantity & Unit value (BRL\$) & Total (BRL\$ ha-1) \\
\hline \multicolumn{6}{|c|}{ A. Mechanized operations } \\
\hline \multicolumn{2}{|c|}{ Sowing of Green manures } & HM & 1.60 & 60.00 & 96.00 \\
\hline \multicolumn{2}{|l|}{ Desiccation } & $\mathrm{HM}$ & 0.15 & 55.00 & 8.25 \\
\hline \multicolumn{2}{|l|}{ Triton } & HM & 0.95 & 55.00 & 52.25 \\
\hline \multicolumn{2}{|c|}{ Sowing of wheat } & HM & 1.30 & 60.00 & 78.00 \\
\hline \multicolumn{2}{|c|}{ Nitrogen fertilization } & $\mathrm{HM}$ & 0.60 & 55.00 & 33.00 \\
\hline \multicolumn{2}{|c|}{ Irrigation } & BRL $\$ m^{-1}$ & 150.00 & 2.00 & 300.00 \\
\hline \multicolumn{2}{|l|}{ Harvest } & Há & 1.00 & 134.00 & 134.00 \\
\hline \multicolumn{6}{|c|}{ B. Manual operations } \\
\hline \multicolumn{2}{|c|}{ Sowing } & HD & 0.20 & 35.00 & 7.00 \\
\hline \multicolumn{2}{|c|}{ Cultural practices } & HD & 0.20 & 35.00 & 7.00 \\
\hline \multicolumn{2}{|c|}{ Harvest } & HD & 0.20 & 35.00 & 7.00 \\
\hline \multicolumn{6}{|l|}{ C. Inputs } \\
\hline \multirow[t]{3}{*}{ 04-30-10 } & & $\mathrm{T}$ & 0.25 & 1.220 .00 & 305.00 \\
\hline & $25 \mathrm{~kg} \mathrm{ha}^{-1} \mathrm{~N}$ & $\mathrm{Kg}$ & 55.5 & 1.22 & 67.71 \\
\hline & $50 \mathrm{~kg} \mathrm{ha}^{-1} \mathrm{~N}$ & $\mathrm{Kg}$ & 111.0 & 1.22 & 135.42 \\
\hline \multirow[t]{3}{*}{ Urea rates } & $-75 \mathrm{~kg} \mathrm{ha}^{-1} \mathrm{~N}$ & $\mathrm{Kg}$ & 166.5 & 1.22 & 203.13 \\
\hline & $100 \mathrm{~kg} \mathrm{ha}^{-1} \mathrm{~N}$ & $\mathrm{Kg}$ & 222.0 & 1.22 & 270.84 \\
\hline & $125 \mathrm{~kg} \mathrm{ha}^{-1} \mathrm{~N}$ & $\mathrm{Kg}$ & 277.5 & 1.22 & 338.55 \\
\hline \multicolumn{2}{|c|}{ Atanor (Glyphosate) } & $\mathrm{L}$ & 4.0 & 5.25 & 21.00 \\
\hline \multicolumn{2}{|c|}{ DMA 806 BR (2,4-D) } & $\mathrm{L}$ & 0.5 & 8.40 & 4.20 \\
\hline \multicolumn{2}{|c|}{ Futur 300 - seed treat. (Wheat) } & $\mathrm{L}$ & 0.8 & 103.00 & 82.40 \\
\hline \multicolumn{2}{|c|}{ Guandu BRS Mandarim } & $\mathrm{Kg}$ & 12.0 & 3.80 & 45.60 \\
\hline \multicolumn{2}{|c|}{ Millet BRS 1501} & $\mathrm{Kg}$ & 15.0 & 1.50 & 22.50 \\
\hline \multicolumn{2}{|c|}{ Crotalaria juncea } & $\mathrm{Kg}$ & 15.0 & 6.50 & 97.50 \\
\hline \multicolumn{2}{|c|}{ Wheat IAC 370} & $\mathrm{Kg}$ & 160.0 & 1.10 & 176.00 \\
\hline
\end{tabular}

HM - machine hour (field time). HD - hour day. 
Besides the benefits that legumes provide to soil, pigeonpea can also be used in cattle feeding and reduce up to $21 \%$ the feeding costs (Embrapa, 2009). Expenses concerning seed acquisition were lower with the use of pigeon pea, with values $46.8 \%$ lower than crotalaria seeds.

Among the green manures, the use of millet as soil cover resulted in the lowest production costs. However, in the case under study, the succession of grasses in the same area may increase the occurrence of diseases, pests and weeds, which would go against the principles of notill farming that recommend not only the no-tillage of the soil, but also keeping the straw on the surface and crop rotation. The market supply of millet seeds and the expansion of this technology as an option for soil cover crop have brought the prices down, reaching the lowest wheat production costs in the no-tillage system.

The cost/benefit ratio for wheat production costs, yield and gross revenue for each experimental treatment are shown in Table 2. The selection of the green manure species and the possibility of reducing nitrogen topdressing can be evaluated by the benefit /cost ratio, considering the price of $\$ 0.46 \mathrm{~kg}^{-1} /$ wheat grains.
The evaluation of the green manures within each nitrogen rate showed that without nitrogen topdressing application, the benefit/cost ratio above 1 was obtained with pigeon pea, that is, there was profit from the use of pigeon pea in a previous crop as nutrient source for the wheat. Among the green manures, the mixed cropping millet + crotalaria had the revenue equal to the costs, whereas the others had costs above the revenue. Crotalaria was the only green manure that stood out at the rate $25 \mathrm{~kg} \mathrm{~N} \mathrm{ha}^{-1}$, with a $6 \%$ profit over the production costs, while the other green manures resulted in negative profitability rates. Although the legume species in this study perform $\mathrm{N}$ fixation and make it available to plants, they are not capable of providing all the nitrogen necessary for the wheat development. It is also important to remember that before wheat cultivation, the evaluated area was cultivated with rice, which is a highly nitrogen demanding crop.

The benefit/cost ratio obtained at the rate of $50 \mathrm{~kg} \mathrm{~N}$ $\mathrm{ha}^{-1}$ was higher and more profitable with the mixed cropping millet + pigeon pea and millet + crotalaria (1.21 and 1.15 , respectively). Single crops of pigeon pea and

Table 2. Operational cost (EOC), yield, gross revenue and benefit/cost ratio of the wheat crop in relation to nitrogen and green manures, in Selvíria (MS), 2010 (wheat grain price BRL\$ $0.46 \mathrm{~kg}^{-1}$ )

\begin{tabular}{|c|c|c|c|c|c|c|c|c|}
\hline \multirow[b]{2}{*}{ Treatments } & \multicolumn{4}{|c|}{ Without $\mathrm{N}$ topdressing } & \multicolumn{4}{|c|}{25 kg ha $^{-1} \mathrm{~N}$} \\
\hline & $\begin{array}{c}\text { EOC } \\
\text { BRL\$ha }^{-1}\end{array}$ & $\begin{array}{c}\text { Yield } \\
\text { kg ha }^{-1}\end{array}$ & $\begin{array}{l}\text { Revenue } \\
\text { BRL \$ ha }\end{array}$ & $\begin{array}{c}\text { Benef./ } \\
\text { EOC }\end{array}$ & $\begin{array}{c}\text { EOC } \\
{\text { BRL } \$ \text { ha }^{-1}}^{2}\end{array}$ & $\begin{array}{c}\text { Yield } \\
\text { kg ha-1 }^{-1}\end{array}$ & $\begin{array}{c}\text { Revenue } \\
\text { BRL\$ ha' }\end{array}$ & $\begin{array}{c}\text { Benef./ } \\
\text { EOC }\end{array}$ \\
\hline Crotalaria & 1,376 & 2,653 & 1,220 & 0.89 & 1,476 & 3,414 & 1,570 & 1.06 \\
\hline P. pea & 1,324 & 3,107 & 1,429 & 1.08 & 1,424 & 3,054 & 1,405 & 0.99 \\
\hline Millet & 1,301 & 2,202 & 1,013 & 0.78 & 1,401 & 2,746 & 1,263 & 0.90 \\
\hline Fallow & 1,130 & 2,072 & 953 & 0.84 & 1,230 & 2,393 & 1,101 & 0.89 \\
\hline M.+ crot. & 1,338 & 2,908 & 1,338 & 1.00 & 1,439 & 3,081 & 1,417 & 0.98 \\
\hline M.+p. pea & 1,312 & 2,113 & 972 & 0.74 & 1,413 & 2,585 & 1,189 & 0.84 \\
\hline \multirow[b]{2}{*}{ Treatments } & \multicolumn{4}{|c|}{$50 \mathrm{~kg} \mathrm{ha}^{-1} \mathrm{~N}$} & \multicolumn{4}{|c|}{$75 \mathrm{~kg} \mathrm{ha}^{-1} \mathrm{~N}$} \\
\hline & $\begin{array}{c}\text { EOC } \\
\text { BRL\$ha }^{-1}\end{array}$ & $\begin{array}{c}\text { Yield } \\
\text { kg ha-1 }^{-1}\end{array}$ & $\begin{array}{l}\text { Revenue } \\
\text { BRL\$ ha }^{-1}\end{array}$ & $\begin{array}{c}\text { Benef./ } \\
\text { EOC }\end{array}$ & $\begin{array}{c}\text { EOC } \\
{\text { BRL } \$ \text { ha }^{-1}}^{2}\end{array}$ & $\begin{array}{c}\text { Yield } \\
\text { kg ha-1 }^{-1}\end{array}$ & $\begin{array}{c}\text { Revenue } \\
\text { BRL \$ ha' }^{-1}\end{array}$ & $\begin{array}{c}\text { Benef./ } \\
\text { EOC }\end{array}$ \\
\hline Crotalaria & 1,544 & 3,447 & 1,586 & 1.03 & 1,612 & 3,468 & 1,595 & 0.99 \\
\hline P. pea & 1,492 & 3,476 & 1,599 & 1.07 & 1,560 & 3,751 & 1,725 & 1.11 \\
\hline Millet & 1,469 & 3,077 & 1,415 & 0.96 & 1,537 & 3,367 & 1,549 & 1.01 \\
\hline Fallow & 1,298 & 2,801 & 1,289 & 0.99 & 1,366 & 3,306 & 1,521 & 1.11 \\
\hline M.+ crot. & 1,506 & 3,772 & 1,735 & 1.15 & 1,574 & 3,662 & 1,684 & 1.07 \\
\hline M.+p. pea & 1,480 & 3,910 & 1,798 & 1.21 & 1,548 & 3,854 & 1,773 & 1.14 \\
\hline \multirow[b]{2}{*}{ Treatments } & \multicolumn{4}{|c|}{100 kg ha $^{-1} \mathrm{~N}$} & \multicolumn{4}{|c|}{$125 \mathrm{~kg} \mathrm{ha}^{-1} \mathrm{~N}$} \\
\hline & $\begin{array}{c}\text { EOC } \\
\text { BRL\$ha }^{-1}\end{array}$ & $\begin{array}{c}\text { Yield } \\
\text { kg ha }^{-1}\end{array}$ & $\begin{array}{l}\text { Revenue } \\
\text { BRL \$ ha }^{-1}\end{array}$ & $\begin{array}{c}\text { Benef./ } \\
\text { EOC }\end{array}$ & $\begin{array}{c}\text { EOC } \\
{\text { BRL } \$ \text { ha }^{-1}}\end{array}$ & $\begin{array}{c}\text { Yield } \\
\text { kg ha }^{-1}\end{array}$ & $\begin{array}{c}\text { Revenue } \\
\text { BRL\$ ha' }\end{array}$ & $\begin{array}{c}\text { Benef./ } \\
\text { EOC }\end{array}$ \\
\hline Crotalaria & 1,679 & 3,768 & 1,733 & 1.03 & 1,747 & 3,528 & 1,623 & 0.93 \\
\hline P. pea & 1,627 & 3,524 & 1,621 & 1.00 & 1,695 & 3,979 & 1,830 & 1.08 \\
\hline Millet & 1,604 & 3,245 & 1,493 & 0.93 & 1,672 & 3,732 & 1,717 & 1.03 \\
\hline Fallow & 1,434 & 3,179 & 1,462 & 1.02 & 1,501 & 3,602 & 1,657 & 1.10 \\
\hline M.+ crot. & 1,642 & 3,734 & 1,718 & 1.05 & 1,710 & 3,467 & 1,595 & 0.93 \\
\hline M.+p. pea & 1,616 & 3,371 & 1,551 & 0.96 & 1,684 & 3,987 & 1,834 & 1.09 \\
\hline
\end{tabular}

Rev. Ceres, Viçosa, v. 59, n.2, p. 246-253, mar/abr, 2012 
crotalaria were also profitable (1.03 and 1.07 , respectively) but less than in the mixed cropping. The areas with millet and fallow had ratios closer to 1 with the rate of $25 \mathrm{~kg}$ ha ${ }^{1} \mathrm{~N}$. At the rate of $75 \mathrm{~kg} \mathrm{ha}^{-1}$ of $\mathrm{N}$, only the production cost of wheat after crotalaria resulted in revenue below the costs. The other green manures resulted in positive benefit/cost ratios. The possibility of obtaining profit with the rates of 50 and $75 \mathrm{~kg} \mathrm{ha}^{-1} \mathrm{~N}$ increases, since together they showed the highest benefit/cost ratios, especially for the mixed croppings evaluated, which had the highest benefit/cost ratios.

In the present study, the highest profitability levels for the wheat crop were obtained at the rates of 50 and 75 $\mathrm{kg} \mathrm{ha}^{-1} \mathrm{~N}$, which is in agreement with Teixeira Filho et al. (2010), who recommend $50 \mathrm{~kg} \mathrm{ha}^{-1}$ of $\mathrm{N}$ in the form of ammonium sulfate for cultivars IAC 370 and E 21 in a notillage system. Similar results were reported by Trindade et al. (2006), who obtained economically viable results using $73 \mathrm{~kg} \mathrm{ha}^{-1} \mathrm{~N}$ in Goiás.

The use of green manure at $100 \mathrm{~kg} \mathrm{ha}^{-1} \mathrm{~N}$ was profitable at 5, 3 and $2 \%$ in the mixed cropping millet + crotalaria, single crotalaria and fallow area, respectively. At $125 \mathrm{~kg}$ $\mathrm{ha}^{-1} \mathrm{~N}$, the fallow area stood out, with approximately $10 \%$ profit over the wheat production costs. It was found that benefit/cost ratio above 1 in the wheat crop was most frequent after the millet and the fallow area at nitrogen levels above $75 \mathrm{~kg} \mathrm{ha}^{-1} \mathrm{~N}$. In the mixed cropping, doses varying from 50 to $75 \mathrm{~kg} \mathrm{~N}^{-1}$ may result in better profits for the wheat crop, besides the benefits of crop rotation to the production system, considering the succession of grasses rice and wheat in this study.

The most costly items in wheat production were the basic and the topdressing fertilizations, considering the wheat production costs in the fallow area representing $27,33,39,45,51$, and $57 \%$ of the production costs at the rates of $0,25,50,75,100$ and $125 \mathrm{~kg} \mathrm{ha}^{-1} \mathrm{~N}$, respectively. Similarly, in the region of Cascavel (PR), fertilizers also represented the highest percentage of the cost $(18.5 \%$ of the total) in the wheat production in a minimum tillage system (SEAB / Deral, 2011).

The use of green manures, such as legume species, can reduce topdressing fertilization in the wheat crop. The evaluation of nitrogen rates after each green manure in single and mixed crops is shown in Figures 1 and 2 respectively.

In the fallow area, the maximum benefit/cost ratio was of 1.05 with the rate of $105 \mathrm{~kg} \mathrm{ha}^{-1} \mathrm{~N}$ (Figure 1). For the millet crop before the wheat, the quadratic equation estimated the maximum cost/benefit ratio as 1.05 , with $100 \mathrm{~kg} \mathrm{~h}^{-1} \mathrm{~N}$. Higher doses would, therefore, increase costs at a higher proportions than revenue. In the crotalaria and pigeon pea, the nitrogen fixation contributed to the reduction of the nitrogen rate, with the maximum point estimated at 1.04 of the benefit/cost ratio and $65 \mathrm{~kg} \mathrm{ha}^{-1} \mathrm{~N}$, in which the cost was equal to the revenue. In the area cultivated with pigeon pea, better results were obtained than with crotalaria: benefit/cost estimated at approximately 1.05 , and $50 \mathrm{~kg} \mathrm{ha}^{-1} \mathrm{~N}$ rate.

Figure 2 shows the curves for the mixed croppings of green manures. The mixed cropping millet + crotalaria showed a maximum point equal to 1.08 of the benefit/cost ratio, with $52.5 \mathrm{~kg} \mathrm{ha}^{-1} \mathrm{~N}$. In the mixed cropping millet + pigeon pea, the values for the benefit/cost ratio were of 1.13 and $81.7 \mathrm{~kg} \mathrm{ha}^{-1} \mathrm{~N}$. Crotalaria contributed more to nitrogen topdressing reduction than pigeon pea, but its high seed cost reduced its benefit/cost ratio.

The initial nitrogen accumulation in the straw from millet + crotalaria intercropping was twice the value found for millet straw. Nitrogen release in the soil 20 days after the management of the mixed cropping was of $170.6 \mathrm{~kg} \mathrm{ha}^{-}$ ${ }^{1} \mathrm{~N}$, whereas for millet in single crop was $102.7 \mathrm{~kg} \mathrm{ha}^{-1} \mathrm{~N}$ (Teixeira et al. 2009). It is important to stand out that the $\mathrm{C} / \mathrm{N}$ ratio of legume straw is lower than that of grasses (Torres \& Pereira, 2008), which helps the action of decomposing microorganisms and accelerates nitrogen mineralization.

According to Camargo et al. (1997), in an area with high response to nitrogen application such as wheat crop succeeding rice, the recommendation for nitrogen fertilization is of $90 \mathrm{~kg} \mathrm{ha}^{-1} \mathrm{~N}$ between 30 and 40 days after emergence. Nitrogen extraction by the rice crop cultivated previously to wheat must be considered, corresponding to $12 \mathrm{~kg}$ of nitrogen per ton of harvested rice. Although the straw from green manure releases quantities of nitrogen above that demanded by wheat, the time of nitrogen release from the straw may occur before the time of the greatest demand from the crop, which according to Teixeira Filho et al. (2010) and Megda et al. (2009), produced the highest yields. The use of green manure does not meet all the nitrogen demand of the wheat crop, especially when in succession to rice, but it may reduce the rates of nitrogen topdressing, especially with legume species, as observed by Braz et al. (2006) for pigeon pea.

Green manures and nitrogen levels influenced the wheat yield. The average productivity of the wheat crop in succession to green manure was higher than the fallow area $\left(2892 \mathrm{~kg} \mathrm{ha}^{-1}\right)$. The single crop of pigeon pea, mixed cropping of millet + crotalaria and single crop of crotalaria produced the highest yields $(3481,3437$ and $3379 \mathrm{~kg}$ ha${ }^{1}$, respectively), differing from the fallow area (Figure 3 ). The results for nitrogen were adjusted to a quadratic equation $\left(\mathrm{y}=2503+20.35 \mathrm{x}-0.09 \mathrm{x}^{2} / \mathrm{R}^{2}=0.94\right)$, where the estimate for the maximum rate of $113 \mathrm{~kg} \mathrm{~N}^{-1}$ provided a production of $3653 \mathrm{~kg} \mathrm{ha}^{-1}$ grains. Cánovas et al. (2004), evaluated the economic viability of wheat in 
Goiás, and obtained yields above $5000 \mathrm{~kg} \mathrm{ha}^{-1}$ (grain), at a production cost of BRL\$ 1,281.00 ha ${ }^{-1}$ in the 2001 harvest. On the other hand, economic data from the 2010 harvest in Mato Grosso do Sul in a rainfed wheat crop in the no-tillage system, indicated production cost of BRL\$ $1,258.00 \mathrm{ha}^{-1}$, with a negative margin of $11 \%$, and loss of
BRL\$ $124.00 \mathrm{ha}^{-1}$. Significant price oscillations for the wheat bushel reduce farmers' income. In June 2006 the wheat bushel was traded at BRL\$19.42. In May 2008, it reached BRL\$ 41.01. Since then, the prices underwent several drops until it reached the value of BRL\$22.93/ bushel in July 2010 (Agrianual, 2011).

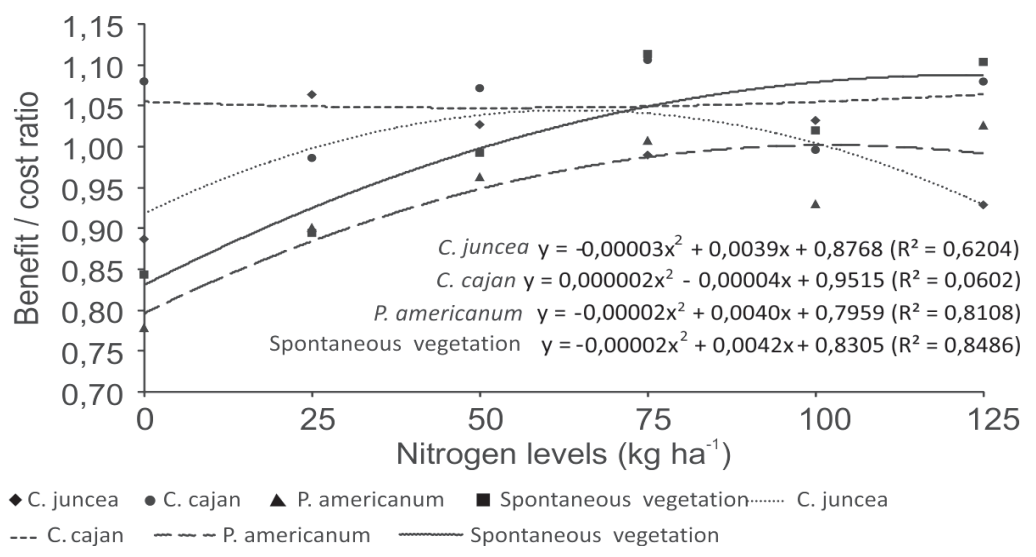

Figure 1. Benefit/cost index of wheat influenced by nitrogen rates and the green manure crotalaria, pigeon pea and millet compared with fallow area in Selvíria (MS), 2010.

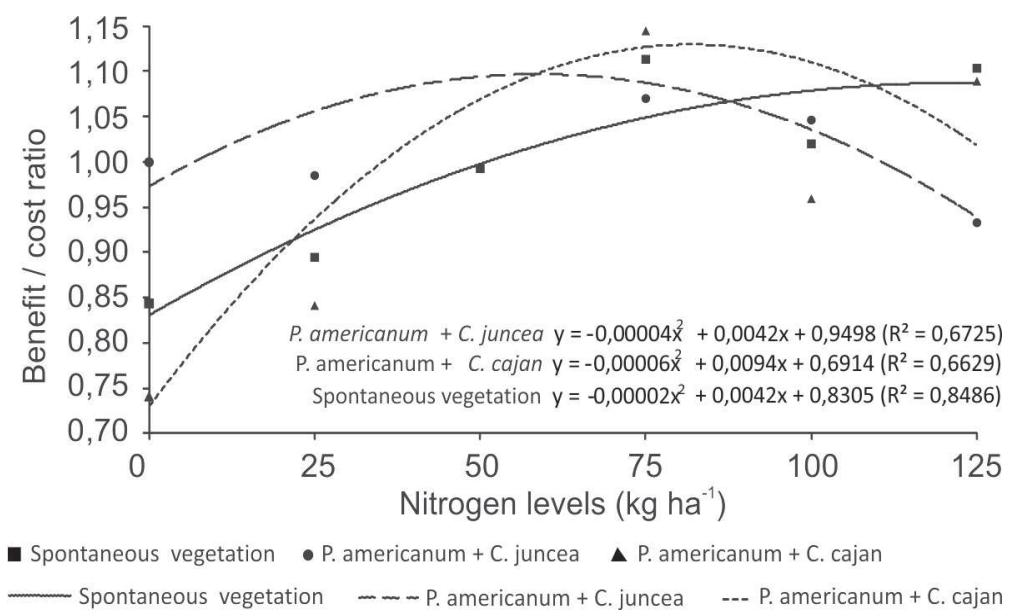

Figure 2. Benefit/cost index of wheat influenced by the mixed croppings millet + crotalaria and millet + pigeon pea compared with fallow area in Selvíria (MS), 2010.

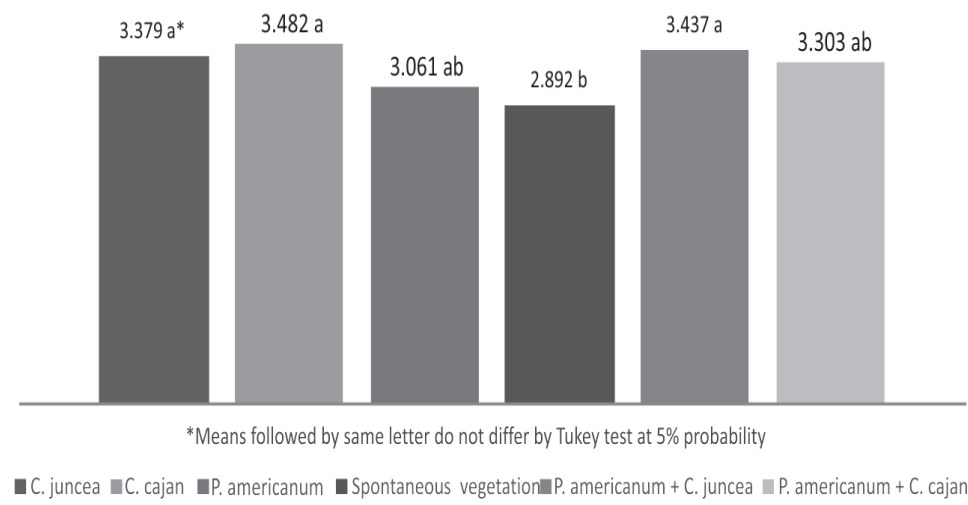

Figure 3. Mean yields of wheat grown under no-tillage after cultivation of the green manures crotalaria, pigeon pea, millet, millet + crotalaria, millet + pigeon pea and fallow area in Selvíria (MS), 2010.

Rev. Ceres, Viçosa, v. 59, n.2, p. 246-253, mar/abr, 2012 


\section{CONCLUSIONS}

The wheat crop in succession to rice in an area previously cultivated with green manure, without nitrogen topdressing and using a $\mathrm{N}$ rate of $25 \mathrm{~kg} \mathrm{ha}^{-1}$, had most frequently production costs above revenue.

The wheat cultivation in an area previously cultivated with millet + pigeon pea and millet + crotalaria associated with nitrogen rates of 50 and $75 \mathrm{~kg} \mathrm{ha}^{-1} \mathrm{~N}$ were more profitable than the treatments with the other green manures.

\section{REFERENCES}

Agrianual (2011) Anuário da agricultura brasileira. iFNP Consultoria \& Comercio; M \& S Mendes \& Scotoni. São Paulo, Editora Agors. 482p.

Anuário do trigo (2001) Diário da manhã. Passo Fundo. 39p.

Braz AJBP, Silveira PM, Kliemann HJ \& Zimmermann FJP (2006) Adubação nitrogenada em cobertura na cultura do trigo em sistema de plantio direto após diferentes culturas. Ciência e Agrotecnologia, 30:193-198.

Camargo CEO, Freitas JG \& Cantarella H (1997) Trigo e triticale irrigados. In: Raij Bvan, Cantarella H, Quaggio JA \& Furlani AMC Recomendações de adubação e calagem para o Estado de São Paulo. 2 ed. rev. atual. Campinas, Instituto Agronômico/ Fundação IAC. p. 70-71. (Boletim Técnico 100)

Cánovas AD, Silva OF da \& Borgui HA (2004) Trigo no cerrado, em se plantando (com tecnologia) dá. In: $12^{\circ}$ Reunião da Comissão Centro-brasileira de Pesquisa de Trigo e $1^{\circ}$ Seminário Técnico de Trigo, Passo Fundo. Resumos, EMBRAPA/CNPT. p. 43-47.

Caviglia OP \& Sadras VO (2001) Effect of nitrogen supply on crop conductance, water and radiation-use efficiency of wheat. Field Crops Research, 69:259-266.

Conab (2011) Acompanhamento da safra brasileira: grãos: Quinto levantamento de grãos da safra 2010/2011, fevereiro 2011/ Companhia Nacional de Abastecimento. Brasília, Conab. Disponível em: < www.conab.gov.br>. Acessado em: 18 de Fevereiro de 2011 .

Embrapa (2011) Agrobiologia: Crotalária. Disponível em: < http:/ /www.cn pab.embrapa.br/publicacoes/leguminosas/ crotalaria.html>. Acessado em: 19 de Fevereiro de 2011.

Embrapa (2009) BRS Mandarim é o novo feijão guandu. Disponível em: <http://www.embrapa.br/imprensa/noticias/2009/janeiro/4a-semana/brs-mandarim-e-o-novo-feijao-guandu/>. Acessado em: 22 de Fevereiro de 2011.

Instituto de economia agrícola - IEA (2011) Banco de dados: preços médios recebidos pelos produtores. Disponível em: http:/ /ciagri.iea.sp.gov.br/bancoiea/Precos_Medios.aspx?cod_sis=2> Acessado em: 18 d Fevereiro de 2011.

Lamothe AG (1998) Fertilización con N y potencial de rendimiento em trigo. In: Kohli MM, Martino DL (Eds.) Explorando altos rendimientos de trigo. Montevideo, CIMMYT/INIA. p. 207246 .

Li J \& Rao M (2003) Field evaluation of crop yield as affected by nonuniformity of sprinkler-applied water and fertilizers. Agricultural Water Management, 59:1-13.

Matsunaga M, Bemelmans PF, Toledo PNE de, Dulley RD, Okawa H \& Peroso IA (1976) Metodologia de custo de produção utilizada pelo IEA. Agricultura em São Paulo, 23:123-139.
Megda MM, Buzetti S, Andreotti M, Teixeira Filho MMC \& Vieira MX (2009) Resposta de cultivares de trigo ao nitrogênio em relação às fontes e épocas de aplicação sob plantio direto e irrigação por aspersão. Ciência e Agrotecnologia, 33:10551060 .

Melo AMT, Betti JA, Pizzinato MA, Dechen SCF \& Freitas SS (1999) O Agronômico: Trigo IAC 370 Armageddon. Campinas, $38 \mathrm{p}$.

Seab/Deral (2011) Estimativa de custos das culturas, Secretaria de Estado da agricultura e do abastecimento do Paraná/Departamento de economia rural. Curitiba, Seab/Deral. Disponível em: < http://www.seab.pr.gov.br/>. Acessado em: 20 de Fevereiro de 2011 .

Sylvester-Bradley R, Stoker DT \& Scott RK (2001) Dynamics of nitrogen capture without fertilizer: the baseline for fertilizing winter wheat in the UK. Journal of Agricultural Science, 136:1533.

Teixeira CM, Carvalho GJ, Andrade MJB, Silva CA \& Pereira JM (2009) Decomposição e liberação de nutrientes das palhadas de milheto e milheto + crotalária no plantio direto do feijoeiro. Acta Scientiarum. Agronomy. 31:647-653.

Teixeira Filho MCM, Tarsitano MAA, Buzetti S, Bertolin DC, Colombo AS \& Nascimento V (2010) Análise econômica da adubação nitrogenada em trigo irrigado sob plantio direto no cerrado. Revista Ceres, 57:446-453.

Trindade MG, Stone LF, Heinemann AB, Cánovas AD \& Moreira JAA (2006) Nitrogênio e água como fatores de produtividade do trigo no cerrado. Revista Brasileira de Ciência Agrícola e Ambiental, 10:24-29.

Zagonel J, Venância WS, Kunz RP \& Tanamati H (2002) Doses de nitrogênio e densidades de plantas com e sem regulador de crescimento afetando o trigo, Cultivar OR-1. Ciência Rural, 32:2529. 